\title{
XII. Cadmium standard cells
}

\author{
John Henderson D.Sc. A.I.E.E.
}

To cite this article: John Henderson D.Sc. A.I.E.E. (1899) XII. Cadmium standard cells , Philosophical Magazine Series 5, 48:290, 152-156, DOI: 10.1080/14786449908621314

To link to this article: http://dx.doi.org/10.1080/14786449908621314

$$
\text { 曲 Published online: } 08 \text { May } 2009 .
$$

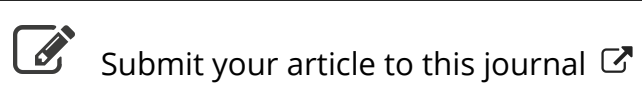

\footnotetext{
Џll Article views: 2
}

Q View related articles $\sqsubset$ 
have its lowest values. Assuming these results, interpret them in the language of the undulatory theory of light."

If we suppose that $R=0$,

and

$$
\frac{1}{v^{2}}=\stackrel{\rho}{\widetilde{\mathrm{E}}}+\frac{\sigma}{\mathrm{E}} \frac{p^{2}}{p^{2}-n^{2}}
$$

$$
\mu^{2}=\frac{v_{0}^{2}}{v^{2}}=1+\frac{\sigma}{\rho} \frac{p^{2}}{p^{2}-n^{2}},
$$

if $v_{0}$ be the velocity corresponding to $\sigma=0$.

XII. Cadmium Standard Cells. By John Hexderson, D.Sc., A.I.E.E., Head of the Physical Department, Borough Polytechnic Institute, London, S.E.*

THE following paper contains an account of the results 1 of experiments on a special form of cadmium cell, which were made by the author in order to clear up several points of considerable importance on which information was necessary if the cell is to be employed as a standard of electromotive force.

The points specially investigated in this research were the following:-

(1) To see how far reliance might be placed in cadmium cells constructed with chemicals ordinarily described as "pure," but not specially purified.

(2) To try the effect of constructing the cell, using moist crystals of $\mathrm{CdSO}_{4}$ in place of a saturated solution of $\mathrm{CdSO}_{4} \dagger$.

(3) To investigate the effect on the E.M.F. of employing " acid" instead of neutral salts.

(4) To measure the temperature-coefficient.

(5) To investigate the nature of the time lag of E.M.F.

(6) To test the rate of recovery of the cells from polarization.

On account of the large temperature coefficient of the Clark cell and the uncertainty as to the exact value of its E.M.F., it was decided not to use it as the standard of E.M.F. in the following measurements, but to compare the various cells with one cadmium cell, the value of the E.M.I. of which, preliminary experiments had shown to have settled down to a constant value. This cell was always kept at the same temperature throughout all the experiments, its E.M.F.

* Commuuicated by the Author.

+ When this research was commenced, owing to the absence of any published description, the author was unaware that crystal cells had been constructed previously by Prof. Callendar. 
Dr. J. Henderson on Cadmium Standard Cells. 153

being determined by balancing it against the fall of potential down a standard resistance carrying a current which was accurately measured on a Kelvin current-balance. The value obtained was 1.0190 volt at $21^{\circ} .5 \mathrm{C}$. The comparisons of E.M.F. were made on a specially constructed manganin potentiometer which was carefully calibrated before the experiments were made.

Three sets of cadmium cells were set up altogether, Sets I. and II. being crystal cells, whilst those in Set III. were made up in H-shaped glass vessels, with a saturnted solution of $\mathrm{CdSO}_{4}$ in place of crystals.
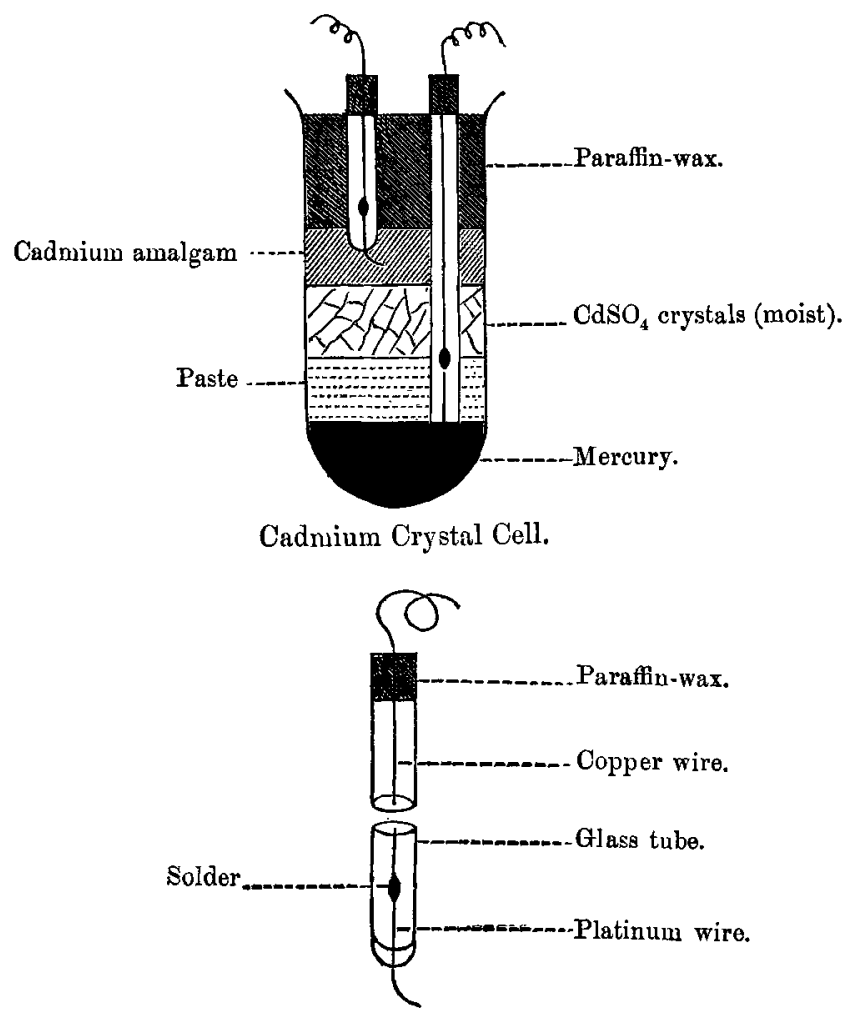

Enlarged View of Contact-wire.

The results obtained from Set III. were, however, very unsatisfactory, in one case a variation of as much as 0.27 per cent. being found to exist between two of the cells at the same temperature.

The accompanying diagrams give an idea of the method of construction of the crystal cells in Sets I. and II. 
In Set I. six cells were set up, the chemicals employed being purchased as pure at an ordinary chemical store. On testing the sulphates both the $\mathrm{CdSO}_{4}$ and $\mathrm{Hg}_{2} \mathrm{SO}_{4}$ were found to be strongly acid. The paste used in all the cells consisted of a mixture of $\mathrm{CdSO}_{4}, \mathrm{Hg}_{2} \mathrm{SO}_{4}$, distilled water, and mercury, whilst the cadmium amalgam had the composition $6 \mathrm{Hg}$ to $1 \mathrm{Cd}$ by weight.

In Set II. six cells were also made up, bat the chemicals employed were specially purified, and were obtained from Messrs. Kahlbaum of Berlin; careful tests showed that both the $\mathrm{CdSO}_{4}$ and $\mathrm{Hg}_{2} \mathrm{SO}_{4}$ were perfectly neutral. The compositions of paste and amalgam were the same as in Set $I$. One cell in each set, however, was specially acidified by making up the paste and moistening the $\mathrm{CdSO}_{4}$ crystals with a 20-per-cent. mixture of $\mathrm{H}_{2} \mathrm{SO}_{4}$ and water, instead of distilled water, in order to examine the effect of added acid.

The results of over two hundred observations of E.M.F. at different temperatures have been summarized in the following tables; the numbers, however, do not include the results obtained from the specially acidified cells.

SET I.

\begin{tabular}{|c|c|c|c|}
\hline Temp. ................ & $10^{\circ}-15^{\circ} \mathrm{O}$ & $15^{\circ}-20^{\circ} \mathrm{C}$ & $20^{\circ}-30^{\circ} \mathrm{O}$. \\
\hline E.M.F. (volts) .......... & 1.0186 & 1.0187 & 1.0180 \\
\hline $\begin{array}{c}\text { Maximum variation } \\
\text { from mean (volts) }\end{array}$ & .0002 & .0001 & 0002 \\
\hline
\end{tabular}

SET II.

\begin{tabular}{|c|c|c|}
\hline Terp................... & $10^{\circ}-15^{\circ} \mathrm{C}$. & $15^{\circ}-20^{\circ} \mathrm{C}$. \\
\hline E.M.F. (rolts) ...... & 1.0188 & 1.0187 \\
\hline $\begin{array}{c}\text { Maximum variation } \\
\text { frum mean (rolts) }\end{array}$ & .0001 & .0001 \\
\hline
\end{tabular}

It will be noticed that the cells in both sets agree very closely amongst themselves.

The results obtained from the specially acidified cells show higher values for the E.M.F. (about 1.0191), and they do not agree so well among themselves. 
It will also be noticed that the values obtained for Set I. are practically identical with those obtained for Set II., which indicates one very important advantage which these cells possess, namely that it is a matter of indifference whether neutral or acid salts are employed in their construction, provided acid is not added.

\section{Temperature-Coeficient.}

The temperature-coefficient of the cells was calculated from the results of the E.M.F. observations at different temperatures, and the mean value obtained for Set I., exclusive of the cell with added acid, was 005 per cent. per $1^{c} \mathrm{C}$., the maximum being 009 per cent. and the minimum value 002 per cent. For Set 1I., exclusive of the acid cell, the mean value was -003 per cent. per $1^{\circ} \mathrm{C}$., the maximum being 004 per cent. and the minimum 002 per cent. The coefficient for the acid cells was larger in both eases, being 007 per cent. for the Set I. cell, and $\cdot 006$ per cent. for the Set II. cell, thus showing very clearly one effect of added acid.

\section{Time-Lag.}

In all the cells the experiments had pointed to the existence of a considerable lag of the E.M.F. behind the temperaturechange; and in order to get some idea of the amount of this lag, cells from each set were kept for some hours at a constant temperature and then placed in a water-bath at a considerably higher temperature; the E.M.F. was measured at stated intervals until it became constant. In all cases the E.M.F. showed a sudden drop on first heating, the amount increasing with the acidity of the cell, and being about - 2 per cent. for cells in Set II. when the temperature was suddenly changed from $166^{\circ} \mathrm{C}$. to $30^{\circ} \mathrm{C}$. After the first drop the value rose slowly until after about two hours it became constant.

\section{Recovery from Polarization.}

Very satisfactory results were obtained from these cells with respect to the recovery of E.M.F. after polarization. The E.M.F. of a cell connected in series with a 1000-ohm coil for five minutes was found to have completely returned to its original value 2 minutes after the circuit was broken. Several cells were then short-circuited with thick copper wires for 5 minutes, and 5 minutes after the circuits were broken they had returned to within 0.4 per cent. of their former value, whilst after 10 minutes they had come within 0.2 per cent. of their original E.M.F. If the cells were given a slight charge for about 1 minute from an E.M.F. 
0.01 volt in excess of their proper value they were found to recover almost immediately.

The conclusions drawn by the author from his experiments are that, so far as regards the fulfilment of the conditions necessary for a standard of E.M.F., the cadmium cell is distinctly superior to any modification of Clark cell. The effects of all ordinary impurities are very small, especially the effect of acid salts, which, although they slightly increase the temperature coefficient of the cell, apparently do not affect it in any other way. The effect of added acid, however, increases the E.M.F., and generally makes the cells untrustworthy.

Cadmium cells should not be subjected to large and sudden variations of temperature on account of the large value of the time-lag. As regards the type of the cell employed, the author considers the crystal form the most satisfactory, both on account of its portability and l,ecause the liquid in the cell is sure to be saturated at all temperatures owing to the excess of $\mathrm{CdSO}_{4}$ crystals.

XIII. Denudation and Deposition.

To the Editors of the Philosophical Magazine. GeNTlemen,

T $N$ your June number, Dr. G. J. Stoney, replying to some 1 criticisms of mine, seems anxious to largely widen the area of our differences. I fear, however, that I camnot allow myself the luxury of a discussion on such an interminable subject as the limits of our ignorance of the earth's physicul constitution. My original criticisms were written in the belief that certain numerical results put forward by Dr. Stoney were obtained by applying the ordinary mathematical theory of elasticity to the earth. The results seemed to be based on an elastic constant, the compressibility of glass, the value of which is quoted on p. 373 ; and the remarks on p. 375 seemed to say that while slow plastic changes were believed to exist, they were, for the time being, left out of account.

My eriticisms referred to the serious obstacle that exists to the application of the ordinary mathematical theory of elastic solids to the earth, when one supposes the material so compressible as Dr. Stoney's figures made it. The expressions found for the gravitational strains are so large as to violate the fundamental hypothesis on which the mathematical theory is based, viz., that strains are small quantities whose squares are negligible. The figures quoted by me for the change of radius of an elastic solid earth of the compressibility of glass were intended solely to illustrate this point. 